\title{
Permafrost degradation risk zone assessment using simulation models
}

\author{
R. P. Daanen ${ }^{1}$, T. Ingeman-Nielsen ${ }^{2}$, S. S. Marchenko ${ }^{3}$, V. E. Romanovsky ${ }^{3}$, N. Foged ${ }^{2}$, M. Stendel ${ }^{4,5}$, \\ J. H. Christensen ${ }^{4,5}$, and K. Hornbech Svendsen ${ }^{6}$ \\ ${ }^{1}$ Institute of Northern Engineering, University of Alaska Fairbanks, 306 Tanana Loop, Fairbanks, AK 99775-5860, USA \\ ${ }^{2}$ Dep. Civil Engineering,Technical University of Denmark, Kgs. Lyngby, Denmark \\ ${ }^{3}$ Geophysical Institute, University of Alaska Fairbanks, USA \\ ${ }^{4}$ Danish Meteorological Institute, Copenhagen, Denmark \\ ${ }^{5}$ Greenland Climate Research Centre, Nuuk, Greenland \\ ${ }^{6}$ Greenland Survey, Nuuk, Greenland
}

Received: 7 March 2011 - Published in The Cryosphere Discuss.: 4 April 2011

Revised: 11 October 2011 - Accepted: 8 November 2011 - Published: 24 November 2011

\begin{abstract}
In this proof-of-concept study we focus on linking large scale climate and permafrost simulations to small scale engineering projects by bridging the gap between climate and permafrost sciences on the one hand and on the other technical recommendation for adaptation of planned infrastructures to climate change in a region generally underlain by permafrost. We present the current and future state of permafrost in Greenland as modelled numerically with the GIPL model driven by HIRHAM climate projections up to 2080. We develop a concept called Permafrost Thaw Potential (PTP), defined as the potential active layer increase due to climate warming and surface alterations. PTP is then used in a simple risk assessment procedure useful for engineering applications. The modelling shows that climate warming will result in continuing wide-spread permafrost warming and degradation in Greenland, in agreement with present observations. We provide examples of application of the risk zone assessment approach for the two towns of Sisimiut and Ilulissat, both classified with high PTP.
\end{abstract}

\section{Introduction}

In West Greenland most villages and cities from the 18th and 19th century are located in natural bays with gentle relief that provide a good harbour and the opportunity to construct houses making use of bedrock exposure for a

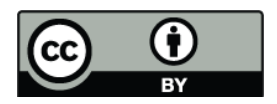

Correspondence to: R. P. Daanen (rdaanen@alaska.edu) stable foundation. However, population and tourism pressure and the increasing need for infrastructure forces construction onto more challenging ground with deeper unconsolidated sediments and ice rich permafrost. In such areas risk assessment of permafrost dynamics are required during the planning of constructions, especially in conjunction with predicted climate warming (IPCC, 2001; ACIA, 2004; IPCC, 2007). Currently there is no guidance for engineers operating in Greenland to account for the effects of climate change; in this paper we introduce a concept and demonstrate how the risk of climate warming can be evaluated for engineering projects.

In most of the inhabited parts of West Greenland, bedrock is generally observed in outcrop or very near to the ground surface. Sediments are mainly found in local bedrock depressions. All of Greenland was ice covered during the last glaciation (Weichsel-Wisconsin), and the ice retreated from the west coast around 10000 years ago (Bennike and Björck, 2002; Roberts et al., 2009). At that time, the local sea level is expected to have been 70 to $150 \mathrm{~m}$ above the present level (Rasch, 2000), and a series of marine silt and clay rich sediments were deposited on the sea bottom. Isostatic rebound (Weidick, 1976) has resulted in the exposure of the marine sediments to the cold climate a.s.l. The sedimentary deposits are often poorly drained, but over thousands of years precipitation has depleted the salts in the upper layers (Foged, 1979), and organic horizons have developed at the surface. The extent of the depletion process differs from region to region, due to differences in the timing of uplift and the formation of ice rich permafrost in the upper depleted portion of the sediment filled basins. 
Previous estimation of permafrost distribution was based mainly on air temperature observations and simulations (Christiansen and Humlum, 2000). The spatial distribution of the observations is very limited and, in addition, the landscape is not conducive to interpolation of climate data over larger distances, due to complex and steep topography and coastal effects. Detailed information on spatial distribution of soil temperatures remains unavailable in the ice free terrestrial portion of Greenland. In this work we have created a dataset that provides modelled soil temperature and active layer depth data at a $25 \mathrm{~km}$ resolution over the ice free part of Greenland, which we will use with additional local information in a risk assessment methodology. The $25 \mathrm{~km}$ resolution data provides a rough estimate of the thermal conditions of the permafrost and we will use this data as a proof of concept. The data set includes both bedrock and sediment calculated temperature and active layer depth, providing a range of ground conditions using the same climate projection as a driver.

Current risk assessment strategies, see e.g. (Nelson et al., 2001), are complex in their decision schemes. To simplify and downscale this procedure we propose to apply the results from our spatially distributed permafrost model to estimate the regional risk of permafrost degradation over terrestrial Greenland, with a concept we call the Permafrost Thaw Potential (PTP).

In this paper we first present the results of regional permafrost simulations for Greenland based on state-of-the-art modelling. We then propose a new simplified risk zonation procedure for permafrost degradation based on substrate, ice content and the regional permafrost thaw potential. As an example of the impact at community level, we will discuss the application of our risk assessment strategy for the towns of Ilulissat and Sisimiut, both located in West Greenland.

\section{Methods}

The estimated PTP will be based upon data from a particular permafrost model (the GIPL model, see Sect. 2.1.1), which receives its input from a chain of models. A "driving" global climate model (GCM) is set up only bound with observed conditions representing the past (e.g., 1850), otherwise the model system is run freely. Because of spin-up, usually several years in the beginning of the simulation are discarded (in this case 100, so only data from 1950 on is used). The atmosphere, ocean, cryosphere etc. model components exchange fields periodically (for example, precipitation is a flux from the atmosphere to the ocean, while evaporation is a flux from the ocean to the atmosphere), but no further observations whatsoever are used. This implies that the simulated situation on a particular day, month, year or even decade cannot directly be compared to the observed weather or climatic state actually observed the same date. However, a "good" climate model is constructed to have the same statistical properties as the observed climate. The GCM we apply (ECHAM5/MPI-OM1, see later for details) has in this respect been compared to many other models for the Arctic (Walsh et al., 2008) and turned out to be one of the most realistic models. Further to this, we note that this disconnection from the real world events is also evident in the permafrost simulations as the involved chain of models are only using model generated information as input to the simulations.

\subsection{Regional permafrost modelling}

\subsubsection{Modelling framework and climatic forcing}

Modelling permafrost on a regional scale is not a straightforward task. Since thawing of permafrost, in particular if it is ice-rich, is subject to a time lag due to the release of latent heat of fusion of ice, it can persist in deep layers for centuries or even millennia (e.g. Stendel and Christensen, 2002). With state-of-the-art global climate models, it is not possible to model these processes, since even advanced surface schemes only in a few cases (Nicolsky et al., 2007) treat soil properties below a depth of a few meters explicitly. In other words, realistic permafrost properties cannot be obtained directly from the model. Furthermore, soil thawing and freezing processes are not considered directly because present models are too coarse to resolve the heterogeneous soil properties in the Arctic (and elsewhere).

Avoiding the traditional and simple approach via "degreedays" based on near-surface temperatures (Anisimov and Nelson, 1997; Stendel and Christensen, 2002), we have decided to run a sophisticated permafrost model with boundary conditions taken from a regional climate model providing higher resolution than what can be offered by a GCM. This approach, discussed in detail in Stendel et al. (2007), offers the advantage that the permafrost model can be run on the grid of the regional climate model, i.e. in much higher spatial resolution than previous approaches. As mentioned above, we use the state-of-the-art global climate model ECHAM5/MPI-OM1 (Marsland et al., 2003; Roeckner et al., 2006; Jungclaus et al., 2006). The model is run with observed values for greenhouses gas and CFC concentrations for the period 1950-2000 and follows IPCC scenario A1B (Nakicenovic et al., 2000) thereafter up to 2100 (May, 2008). The horizontal resolution is T63, which is approximately $1.875^{\circ}$ in latitude and longitude (or $\sim 200 \mathrm{~km}$ ). Output from this model is used to create boundary conditions for the regional climate model HIRHAM4 (Christensen et al., 1996), which can be considered a high-resolution, limitedarea version of ECHAM5 (see detailed discussion in Stendel et al., 2008a). Finally, output fields from the RCM are used to create boundary conditions for the permafrost model.

As indicated above, many permafrost models with a variety of applications have been proposed during the last 20 years (Nelson and Outcalt, 1987; Christensen and Kuhry, 
2000; Anisimov et al., 2002; Romanovsky et al., 2002; Stendel and Christensen, 2002; Sazonova and Romanovsky 2003; Riseborough et al., 2008). In our study, we use a numerical simulation model called GIPL 2.1, a parallelized version of GIPL 2.0 (Tipenko, 2001; Sergeev et al., 2003) for simulating spatially distributed ground temperatures over the ice free part of Greenland. GIPL 2.1 is a state-of-the-art numerical model which takes a temperature-dependent latent heat effect into account (Marchenko et al., 2008).

Complex topography and coast line are key characteristics of Greenland. To fully resolve these features requires very high spatial resolution of climate as well as permafrost distribution. While a $25 \mathrm{~km}$ resolution reveals useful features (Stendel et al., 2008a), a resolution on the order of $5 \mathrm{~km}$ would be needed to give a fair representation of the coastal topography which strongly influences the temperature distribution at the site level. The next generation climate models will approach this scale by embarking the $5 \mathrm{~km}$ grid scale e.g. (Lucas-Picher et al., 2011). Efforts to utilize this scale also for distributed permafrost modelling in Greenland are under way but too premature to be included in the present analysis. A representative estimate for air temperature is acquired through the application of a medium-high resolution regional climate model (RCM). As mentioned above, we base our analysis on a well-tested RCM HIRHAM4 with a grid cell size of 25 by $25 \mathrm{~km}$ (Dethloff et al., 2002; Rinke et al., 2006; Stendel et al., 2008a). Further downscaling of the results to site level would seem necessary in order to provide a more complete basis for ground truth comparison. But this would introduce using another (statistical) model, which is not our target. The mapping effort we are pursuing here would not necessarily benefit from adding such details as in most areas there is no data for verification available in the first place. Our main goal is to demonstrate how to build a risk strategy based on comprehensive modelling. As such, the present paper should be considered a proof-of-concept study.

\subsubsection{The modelled ground conditions}

The RCM provides data for all of Greenland and surrounding seas and data from the simulation is available for the period 1950 to 2080 (Stendel et al., 2008a). The modelling domain layout used in the GIPL permafrost model is identical to that of the driving RCM, but covers only the ice-free land areas. These areas are dominated by exposed bedrock with sediment filled depressions that are often covered with a layer of organic material. Since our $25 \mathrm{~km}$ grid is much too coarse to resolve the distribution of sediments and bedrock, and due to the vastly different thermal properties of these materials, we chose to split the simulation in two categories: a bedrock simulation and a sediment simulation. The difference between these runs is a lower ground temperature in the sediment run caused by the presence of a greater thermal offset (Romanovsky and Osterkamp, 1995), which is the result of
Table 1. Description of sediment clasification, percentages are a representative area.

\begin{tabular}{l|l}
\hline Group 1 & $\begin{array}{l}\text { Gelisol 60\% (Turbel 25\%, Orthel 35\%), } \\
\text { Inceptisol 30\%, Water 10\% }\end{array}$ \\
Group 2 & Gelisol 70\% (Turbel 60\%), Rockland 30\% \\
Group 3 & $\begin{array}{l}\text { Gelisol 70\% (Turbel 10\%, Orthel 60\%), } \\
\text { Rockland 30\% }\end{array}$ \\
Group 4 & Gelisol 100\% (Turbel 40\%, Orthel 60\%) \\
Group 5 & Gelisol 100\% (Turbel 65\%, Orthel 35\%) \\
Group 6 & Gelisol 100\% (Turbel 80\%, Orthel 20\%) \\
Group 7 & Inceptisol 70\%, Rockland 30\% \\
Group 8 & Spodosol 5\%, Inceptisol 85\%, Water 10\% \\
Group 9 & Spodosol 60\%, Inceptisol 40\% \\
Group 10 & Entisol 30\%, Inceptisol 60\%, Water 10\% \\
\hline
\end{tabular}

thermal conductivity differences between frozen and thawed porous media. The other difference between the permafrost model runs is the reduced porosity of the ground which results in a reduced production/consumption of latent heat for the bedrock simulation in equally saturated conditions. The lack of liquid water and ice, results effectively in faster and deeper warming in spring and summer, as well as faster and deeper cooling in fall and winter. More ice or water in the sediment simulation results in slower changes in temperature around the melting point, but it results also in a greater difference in winter and summer energy transfer rates, which causes the thermal offset.

Soil class descriptions for our sediment run are given in Table 1 and associated thermal properties are given in Table 2 . Both heat capacity and thermal conductivity are calculated using a geometric mean between frozen and thawed states based on the unfrozen water content. The total moisture content is constant in time for GIPL 2.1 used in this study. We do not account for changes in porosity due to loss of permafrost with massive ice structures. On a landscape scale $(25 \mathrm{~km})$ these changes likely balance out due to drying on slopes and wetting in poorly drained areas. The unfrozen water content is calculated according to the following equation based on Lovell (1957): $T<D=>\Theta_{1}=\Theta_{\text {tot }} \times \mathrm{A} \times(\mathrm{D}-$ $\mathrm{T})^{\mathrm{B}}$, where $\Theta_{1}\left[\mathrm{~m}^{3} \mathrm{~m}^{-3}\right]$ is the volumetric unfrozen water content at temperature $T\left[{ }^{\circ} \mathrm{C}\right]$, is the total volumetric water content of the soil, D is the freezing point of the liquid (available to allow adjustment of the freezing point to account for solutes in the domain), and A and B are parameters that vary based on the material in question. The unfrozen water content is truncated to the total water content if $\Theta_{1}>\Theta_{\text {tot }}$.

The first run of our model relates to the sedimentary conditions. For this run we use 10 different ground thermal classes illustrated in Fig. 1. These classes are not based on grain size but rather soil order and distribution. Each climate model node is evaluated for its soil order described in the global soils map published by the Food and Agriculture 
Table 2. Parameters in the sediments classification. For the bedrock simulation, all models are assigned the parameters of the deepest layer of Group 1 (highlighted in the table) except for the volumetric water content which is set to 0.1 in the bedrock simulations. In the column captions $\theta$ is the total volumetric water content, A and B are the parameters of the unfrozen water relationship Lovell (1957), C is the heat capacities and $\lambda$ the thermal conductivities.

\begin{tabular}{|c|c|c|c|c|c|c|c|c|}
\hline Group with description & $\begin{array}{l}\theta \\
{[-]}\end{array}$ & $\begin{array}{l}\boldsymbol{A} \\
{[-]}\end{array}$ & $\begin{array}{l}\boldsymbol{B} \\
{[-]}\end{array}$ & $\begin{array}{l}\boldsymbol{C}_{\text {Thawed }} \\
{\left[\mathrm{J} /\left(\mathrm{m}^{3} \times \mathrm{K}\right)\right]}\end{array}$ & $\begin{array}{l}\boldsymbol{C}_{\text {Frozen }} \\
{\left[\mathrm{J} /\left(\mathrm{m}^{3} \times \mathrm{K}\right)\right]}\end{array}$ & $\begin{array}{l}\lambda_{\text {Thawed }} \\
{[\mathrm{W} /(\mathrm{m} \times \mathrm{K})]}\end{array}$ & $\begin{array}{l}\lambda_{\text {Frozen }} \\
{[\mathrm{W} /(\mathrm{m} \times \mathrm{K})]}\end{array}$ & $\begin{array}{l}\text { Layer thickness } \\
{[\mathrm{m}]}\end{array}$ \\
\hline \multirow[t]{6}{*}{ Group 1} & 0.25 & 0.002 & -0.1 & 1700000 & 1600000 & 0.4 & 0.75 & 0.15 \\
\hline & 0.65 & 0.02 & -0.38 & 2600000 & 2400000 & 0.5 & 1.6 & 0.3 \\
\hline & 0.65 & 0.035 & -0.35 & 2700000 & 2200000 & 0.5 & 1.6 & 1.3 \\
\hline & 0.45 & 0.06 & -0.35 & 2900000 & 2000000 & 0.9 & 2.2 & 3 \\
\hline & 0.4 & 0.05 & -0.35 & 2900000 & 2000000 & 1.2 & 3 & 10 \\
\hline & 0.4 & 0.05 & -0.35 & 2900000 & 2000000 & 0.9 & 2.2 & 20 \\
\hline Bedrock & 0.2 & 0.01 & -0.17 & 2800000 & 2000000 & 2.8 & 3.5 & 1000 \\
\hline \multirow[t]{4}{*}{ Group 2} & 0.25 & 0.002 & -0.1 & 1700000 & 1600000 & 0.6 & 0.75 & 0.05 \\
\hline & 0.65 & 0.035 & -0.35 & 2700000 & 2200000 & 0.8 & 1.6 & 1.3 \\
\hline & 0.45 & 0.06 & -0.35 & 2900000 & 2000000 & 0.9 & 2.2 & 3 \\
\hline & 0.2 & 0.01 & -0.17 & 2800000 & 2000000 & 2.8 & 3.5 & 1000 \\
\hline \multirow[t]{4}{*}{ Group 3} & 0.25 & 0.002 & -0.1 & 1700000 & 1600000 & 0.5 & 0.6 & 0.1 \\
\hline & 0.65 & 0.035 & -0.35 & 2700000 & 2200000 & 0.8 & 1.6 & 1.3 \\
\hline & 0.45 & 0.06 & -0.35 & 2900000 & 2000000 & 0.9 & 2.2 & 5 \\
\hline & 0.2 & 0.01 & -0.17 & 2800000 & 2000000 & 2.8 & 3.5 & 1000 \\
\hline \multirow[t]{6}{*}{ Group 4} & 0.25 & 0.002 & -0.1 & 1700000 & 1600000 & 0.4 & 0.6 & 0.2 \\
\hline & 0.65 & 0.035 & -0.35 & 2700000 & 2200000 & 0.7 & 1.6 & 1.3 \\
\hline & 0.45 & 0.06 & -0.35 & 2900000 & 2000000 & 1.1 & 2.2 & 3 \\
\hline & 0.4 & 0.05 & -0.35 & 3000000 & 1700000 & 1.2 & 3 & 10 \\
\hline & 0.4 & 0.05 & -0.35 & 3000000 & 1700000 & 0.9 & 2.2 & 20 \\
\hline & 0.2 & 0.01 & -0.17 & 2800000 & 2000000 & 2.8 & 3.5 & 1000 \\
\hline \multirow[t]{6}{*}{ Group 5} & 0.25 & 0.002 & -0.1 & 1700000 & 1600000 & 0.6 & 0.8 & 0.15 \\
\hline & 0.65 & 0.035 & -0.38 & 2700000 & 2200000 & 1 & 2 & 1.3 \\
\hline & 0.45 & 0.06 & -0.35 & 2900000 & 2000000 & 1.1 & 2.2 & 3 \\
\hline & 0.4 & 0.05 & -0.35 & 3000000 & 1700000 & 1.2 & 3 & 10 \\
\hline & 0.4 & 0.05 & -0.35 & 3000000 & 1700000 & 0.9 & 2.2 & 20 \\
\hline & 0.2 & 0.01 & -0.17 & 2800000 & 2000000 & 2.8 & 3.5 & 1000 \\
\hline \multirow[t]{5}{*}{ Group 6} & 0.25 & 0.002 & -0.1 & 1700000 & 1600000 & 0.7 & 0.9 & 0.1 \\
\hline & 0.65 & 0.035 & -0.38 & 2700000 & 2200000 & 1 & 2 & 1.3 \\
\hline & 0.45 & 0.06 & -0.35 & 2900000 & 2000000 & 1.1 & 2.2 & 5 \\
\hline & 0.4 & 0.05 & -0.35 & 3000000 & 1700000 & 0.9 & 2.2 & 10 \\
\hline & 0.2 & 0.01 & -0.17 & 2800000 & 2000000 & 2.8 & 3.5 & 1000 \\
\hline \multirow[t]{5}{*}{ Group 7} & 0.25 & 0.002 & -0.1 & 1700000 & 1600000 & 0.4 & 0.75 & 0.3 \\
\hline & 0.45 & 0.06 & -0.35 & 2900000 & 2000000 & 0.9 & 2.2 & 3 \\
\hline & 0.4 & 0.05 & -0.35 & 3000000 & 1700000 & 1.2 & 3 & 10 \\
\hline & 0.4 & 0.05 & -0.35 & 2900000 & 2000000 & 0.9 & 2.2 & 20 \\
\hline & 0.2 & 0.01 & -0.17 & 2800000 & 2000000 & 2.8 & 3.5 & 1000 \\
\hline \multirow[t]{5}{*}{ Group 8} & 0.3 & 0.002 & -0.1 & 1700000 & 1600000 & 0.4 & 0.75 & 0.5 \\
\hline & 0.45 & 0.06 & -0.35 & 2900000 & 2000000 & 0.9 & 2.2 & 3 \\
\hline & 0.4 & 0.05 & -0.35 & 2900000 & 2000000 & 1.2 & 3 & 10 \\
\hline & 0.4 & 0.05 & -0.35 & 2900000 & 2000000 & 0.9 & 2.2 & 20 \\
\hline & 0.2 & 0.01 & -0.17 & 2800000 & 2000000 & 2.8 & 3.5 & 1000 \\
\hline \multirow[t]{4}{*}{ Group 9} & 0.3 & 0.002 & -0.1 & 1700000 & 1600000 & 0.6 & 0.9 & 0.5 \\
\hline & 0.45 & 0.06 & -0.35 & 2900000 & 2000000 & 0.9 & 2.2 & 3 \\
\hline & 0.4 & 0.05 & -0.35 & 3000000 & 1700000 & 1.2 & 3 & 10 \\
\hline & 0.2 & 0.01 & -0.17 & 2800000 & 2000000 & 2.8 & 3.5 & 1000 \\
\hline \multirow[t]{4}{*}{ Group 10} & 0.4 & 0.002 & -0.1 & 1700000 & 1600000 & 0.6 & 0.9 & 0.5 \\
\hline & 0.55 & 0.06 & -0.35 & 2900000 & 2000000 & 0.9 & 2.2 & 3 \\
\hline & 0.4 & 0.05 & -0.35 & 3000000 & 1700000 & 1.2 & 3 & 10 \\
\hline & 0.2 & 0.01 & -0.17 & 2800000 & 2000000 & 2.8 & 3.5 & 1000 \\
\hline
\end{tabular}




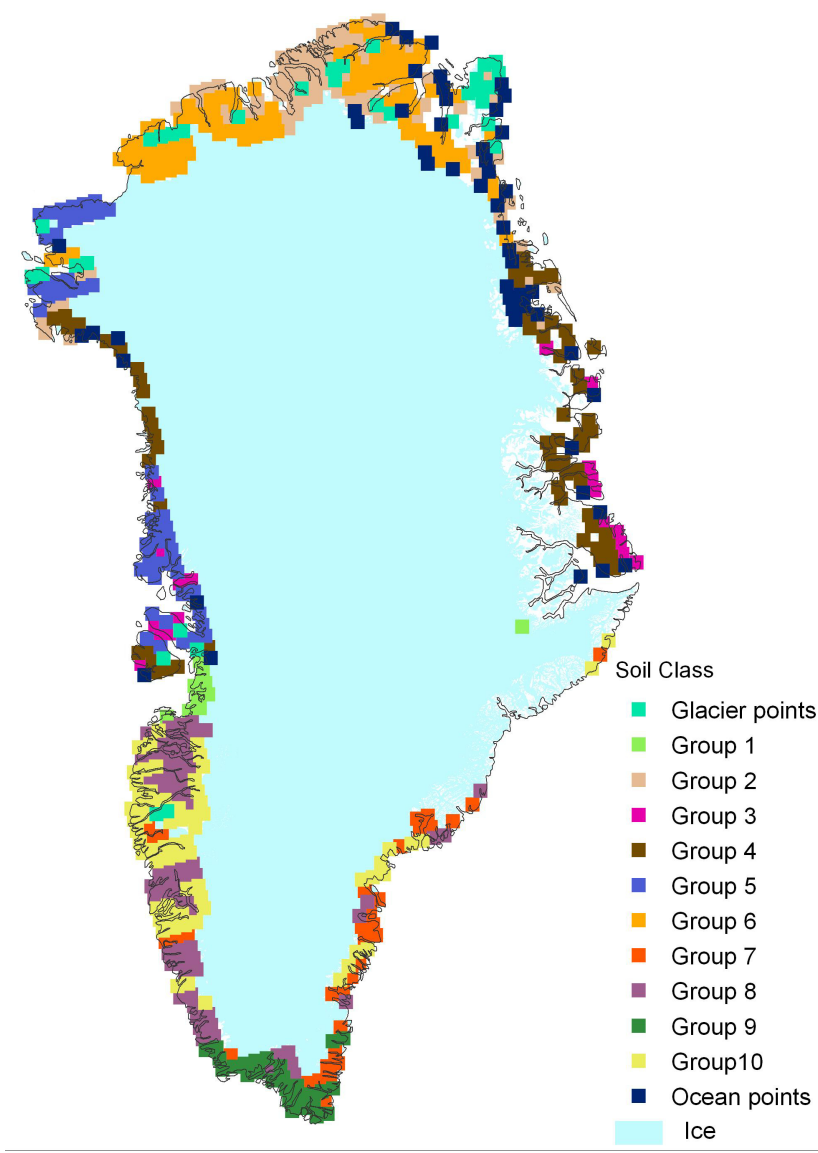

Fig. 1. Soil classification zones, based on soil orders from the Food and Agriculture Organization of the United Nations (1978).

Organization of the United Nations (1978). Extensive research is needed to identify proper soil thermal properties for any region in the world. Due to the lack of data from Greenland we choose thermal properties for this paper via an educated guess. The distribution of the groups is based on the soils map and the thermal properties are based on measurements and ground temperature reconstructions from permafrost regions in Alaska with similar vegetation and soils (Marchenko et al., 2008; Nicolsky et al., 2009). These thermal properties result in a realistic, but cold soil condition for the given climate, because it promotes the thermal offset. None of the classes include layers of soil with a freezing point depression, such as saline soils. For this general model run the variable $\mathrm{D}=0^{\circ} \mathrm{C}$ for all layers in all classes.

Lower boundary conditions for the entire Greenland domain are set to a fixed temperature gradient of $0.018^{\circ} \mathrm{C} \mathrm{m}^{-1}$. The initial temperatures for the model domain model are calculated with a spin-up procedure of 100 years, using repeated climate data from 1955 to 1965.

A different run for the Greenland domain shows the temperature distribution for a bedrock material. The material properties used for this run are kept constant for the entire domain so all variations shown are caused by spatial and temporal variations in the forcing temperature and snow depth. The thermal properties are the same for the entire depth of the profile and set to the values shown in Table 2 for the deepest layer of the first group, except for the moisture content, which is set to 0.1 .

\subsubsection{Treatment of snow in the model}

Snow is an important factor in permafrost temperature development (Goodrich, 1982; Zhang, 2005; Lawrence and Slater, 2008). Snow has a longer term effect on the ice content in the lower part of the active layer. Low snow years may result in increase in the ice content within the lower portion of the active layer and upper permafrost (Daanen et al., 2008) and high snow years in discontinuous permafrost can prevent the freeze-up of the active layer and establish a talik, or a thawed layer in the ground (Yoshikawa and Hinzman, 2003). Bedrock outcrops are likely to experience less snow than the poorly drained low lying pockets of sediment, because the exposed rock outcrop areas are generally windblown.

The scale of the regional climate model HIRHAM, used for this study, does not resolve this sub-grid scale variation between exposed rock and sheltered pockets. Only a blowing snow model, with more detailed topographical input, would be able to simulate these differences, but at the same time only make really sense at a much higher spatial resolution. And still, when based on climate model forcing, the results would still not be directly comparable to observed field data for a specific year. For these reasons - and due to the lack of supporting field data from Greenland - we did not take the potential snow depth difference between bedrock and sedimentary basins into account in our simulations. Thus we have treated snow the same for sediment and bedrock areas, taking the data from the HIRHAM snow water equivalent projections. Snow depth was calculated from snow water equivalent using a constant snow density of $0.15 \mathrm{~kg} \mathrm{dm}^{-3}$ in order to generate snow depth data that are comparable with the measured data from Ilulissat (Olesen, 2003) see Fig. 2. The snow column is included in the finite difference scheme for calculating the ground temperatures. The thermal conductivity for snow was fixed at $0.125 \mathrm{~W} /(\mathrm{m} \times \mathrm{K})$ and the heat capacity is fixed at $0.84 \times 10^{6} \mathrm{~J}\left(\mathrm{~m}^{-3} \times \mathrm{K}\right)$. The discrepancies between observed and simulated snow depths shown in Fig. 2 are due to the model-generated storm patterns, so that intensities differ from real world data. The single point observations are also likely affected by drifting, causing a few measured snow depths much greater than expected from snow fall events in those years.

\subsection{Risk Assessment}

Our risk assessment methodology aims at determining the risk of permafrost degradation resulting in severe settlements based on relatively simple parameters. The intention is that 


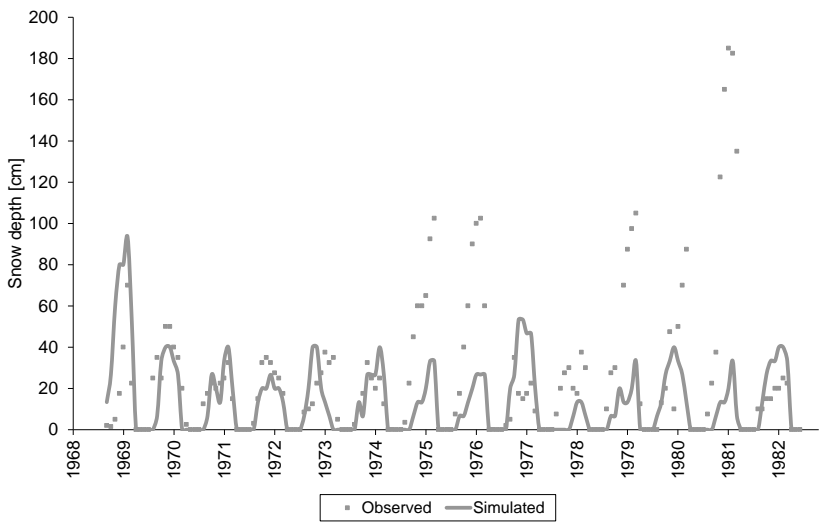

Fig. 2. Observed and simulated snow depth for the Ilulissat region. Observed snow depths are from Olesen (2003).

it should be useful both on a regional scale to produce forecasts of likely scenarios, and with higher resolution input in a site specific context as a decision and planning tool for town planners and engineers in the local municipal governments and consulting businesses in the Greenlandic towns. In the present study we focus on the regional approach in order to produce a risk assessment indicating the likely changes for the 21 st century over the entire Greenland domain.

The methodology is expressed as a flow diagram (see Fig. 3), which classifies the risk in the four categories Low, Limited, Medium and High risk based on environmental properties and a thermal criterion. The three environmental properties are the surface conditions, the sediment type (if applicable) and an evaluation of the ice content in the ground.

Based on the surface properties of the area, it is classified as either bedrock outcrop or sedimentary basin. If the area classifies as bedrock, no special precautions should be made, and standard foundation practices based on rock mass quality, weathering and fracturing assessments can be applied. If, on the other hand, the area classifies as sedimentary basin, a grain size main descriptor is established for the area based on standard engineering geological grain size classification terms. In the flow chart, these main descriptors are grouped according to the material frost susceptibility, with Gravel/Sand having low to negligible frost susceptibility and Silt/Clay having medium to very high frost susceptibility. The third parameter is an evaluation of the actual ice content in the ground. We discriminate between high and low ice content, with high ice content corresponding to volumetric ice content in excess of the natural pore volume of the soil, and low ice content corresponding to ice confined to the natural pore space. The state of these environmental variables are either determined from field investigations or estimated based on background information such as geological maps and modelling efforts. Soils with low ice content classify as limited (Gravel/Sand) or medium risk (Silt/Clay) depending on the grain size main descriptor.

\section{Risk zonation flow diagram}

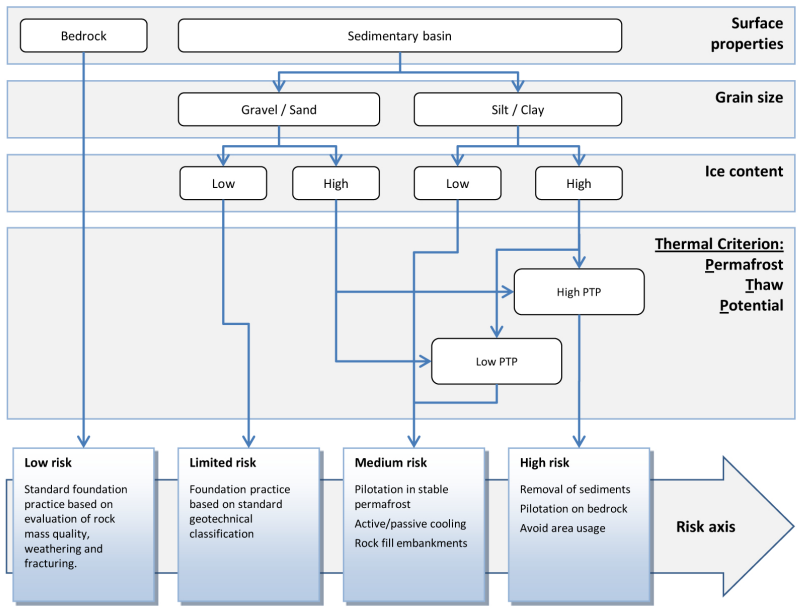

Fig. 3. Risk evaluation decision flow diagram construction permafrost soil or rock. Standard engineering geological main descriptor terms are used in descriminating Gravel, Sand, Silt and Clay. High ice content is defined as greater than porosity and high PTP is defined as greater than $2.5 \mathrm{~m}$.

For soils with high ice content, an additional thermal criterion must be evaluated in order to determine the risk class. Different types of thermal criteria could be used, depending on the scale of the problem considered. In this paper, we have chosen to define and use what we call the Permafrost Thaw Potential (PTP).

\subsubsection{Permafrost thaw potential}

The present permafrost is at risk due to both future climatically induced warming and surface condition changes due to infrastructure development and constructions. The two effects act in a complementary additive fashion. The projected climate induced changes result in increased active layer thicknesses.

The risk arising from infrastructure development on permafrost is also a deepening of the active layer resulting from removal of the insulating organic layer and subsurface material and replacement with for example an embankment and pavement layer. This changes the surface energy balance and the thermal properties of subsurface material. Heat-carrying or producing structures such as housing, pipelines and sewers, produce additional heat conduction into the ground and may induce further thawing.

The regional risk should therefore be evaluated based on simulations of permafrost conditions in the original sedimentary setting and compared to thermal conditions under the forecasted future conditions. We define here the PTP as the potential active layer increase by subtracting the current 
active layer thickness from the expected active layer thickness under the future climatic and surface conditions.

Since these future conditions may vary depending on area usage and thus are not known until the design phase of a particular project, we suggest using the modelled bedrock situation as a proxy for surface disturbance, which would occur due to construction activities. The PTP is thus the potential active layer depth increase from the conditions today to the perturbed future conditions.

In this way the PTP becomes an indication of permafrost "health" over the coming decades taking into account possible future construction effects. To quantify the health of permafrost using the PTP we classified it to high and low intervals with a limiting PTP value of $2.5 \mathrm{~m}$. This value is chosen based on our observations with regard to structures surviving on frozen sediment in the vicinity of the Thule air force base based on US Air Force construction practice.

In the southern part of Greenland, due to our definition, the calculated PTP may exceed the permafrost thickness under present conditions.

\subsubsection{Work flow}

Figure 3 illustrates the risk zone assessment flow diagram for construction in areas with frozen ground in Greenland. The environmental parameters resulting in different risk classifications are indicated as horizontal tabs, and the resulting risk classes are indicated along the risk axis at the bottom together with typical foundation solution recommendations for each class.

The general work flow in applying the risk assessment is to:

1. Evaluate surface properties: Bedrock, soil/vegetation and ice content

2. Establish an engineering geological model of the area

3. Produce projection of future ground temperature regime and calculate PTP

4. Risk evaluation according to the flow chart.

\section{Results}

\subsection{Permafrost Simulation}

The Greenland simulation results presented are 10 year average temperatures centred on the years 1960, 2000 and 2070 at $2 \mathrm{~m}$ depth. These data show an average increase of $1.3^{\circ} \mathrm{C}$ in air temperature for the entire ice free portion of Greenland. Most of this warming is concentrated in the northern regions, with much less warming along the coast in the southwest where most communities are located. The simulation result using bedrock substrate shows that the 10 year mean temperature at 2 meters below the surface is projected to increase by $1.6^{\circ} \mathrm{C}$ while this value for the sediment case is $2.0^{\circ} \mathrm{C}$. The spatial trend of the ground temperatures is similar to that of the air temperature with most warming occurring in the north. Bedrock thaw depths will increase by $1.4 \mathrm{~m}$ on average for Greenland. The active layer in sediment is projected to increase by $0.4 \mathrm{~m}$ between current and future conditions; the active layer depth varies strongly from north to south with the greatest increases in active layer occurring in the south.

Figure 4a shows the temperature distribution in bedrock material over Greenland at the $25 \mathrm{~km}$ resolution solely based on model information. The first image shows the ten year average ground temperature from 1955 to 1965 for a depth of $2 \mathrm{~m}$, the second images gives the same parameter for recent soil climatic conditions (1995-2005) at the same depth, and the third image is a projection into the future soil climate for the late-century simulation period. Figure 4 a shows warming over most of the simulated area. In bedrock the temperature fluctuation between summer and winter are larger than in the sediment due to strongly reduced amount of ice or liquid water that buffers the temperature fluctuation (Romanovsky et al., 2010). Figure $4 \mathrm{~b}$ shows the active layer depth for the beginning (left), middle and the end (right) of the simulation period. The active layer depth reflects the same limited buffer capabilities with deep summer effective active layer depths in the bedrock of more than $3 \mathrm{~m}$ the south and less than three meters in the north. A few simulation regions in the south east seem to convert to ice sheet during some years affecting the soil thermal regime, this is a climate model artefact and not a soil thermal difference.

For undisturbed sediment we found cooler average temperatures due to a greater the thermal offset in the upper soil layers compared to bedrock simulations. The $2 \mathrm{~m}$ temperature and active layer results for the sediment simulations are given in Fig. 5a and b respectively. The results show a warming trend over our simulation period and a deepening of the active layer. Most of the warming occurs in winter which leads to warmer permafrost, but not directly to a deeper active layer in the northern portion of Greenland. However in the south summer temperatures also increase and active layer depths are strongly affected. The simulations also project that permafrost in the southernmost sediment regions disappears completely, and that the southern boundary of permafrost affected areas is expected to migrate north by approximately $100 \mathrm{~km}$.

\subsection{Risk assessment for the Greenland domain}

Figure 6 shows the PTP classification for the entire Greenland domain evaluated based on the 1995-2005 sediment condition simulation and the 2065-2075 bedrock condition simulation.

Our choice of $2.5 \mathrm{~m}$ as the limiting PTP value between high and low classification was based on experience from the Thule area, placing Thule Air Force Base in a transitional area from low risk to high risk. This choice is supported by 


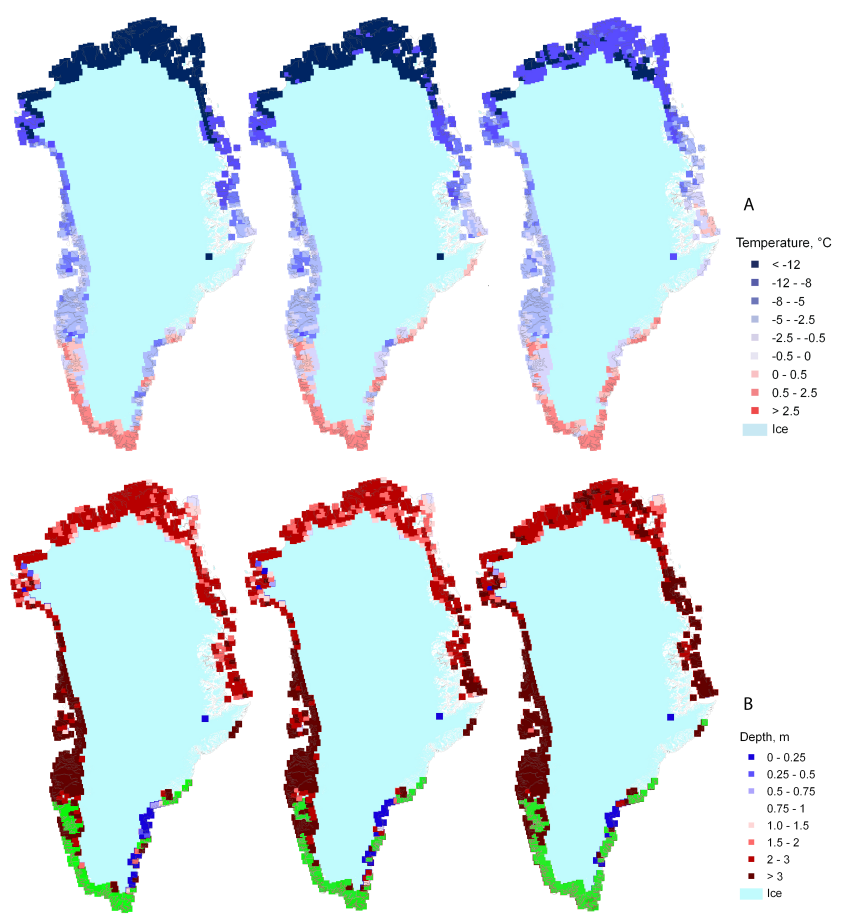

Fig. 4. (A) Bedrock temperature distribution at $2 \mathrm{~m}$ depth for an average over the periods 1955-1965, 1995-2005, and 2065-2075. (B) Active layer depth distribution in bedrock for an average over the periods 1955-1965, 1995-2005, and 2065-2075. The green color represents a permafrost free zone.

observed settlement of large structures on the Air Force Base. Modern buildings with sophisticated cooling mechanism are stable whereas older buildings without these systems settle (Birkholm et al., 2007).

According to the modelling results most of the terrestrial portion of Greenland has a PTP above $2.5 \mathrm{~m}$ and thus classify as high Permafrost Thaw Potential according to our choice of limiting value. This means that throughout the inhabited part of Greenland, sedimentary basins may classify as high risk areas in the risk zonation evaluation according to Fig. 3, provided the sediments have high ice contents.

During our study, we have observed significant stability problems for roads and buildings on permafrost in the towns of Ilulissat and Sisimiut, which are located in areas with wide spread presence of fine grained marine deposits with high ice content, whereas a town such as Aasiaat, which is located in an area of mainly coarse grained sediments with low ice contents, does not seem to experience thaw related stability problems. This supports our decision making algorithm by showing that areas classified with high PTP may in fact have high or limited risk depending on grain size and ice content classification. In spite of the apparently plain and obvious appearance of the PTP class map, we do conclude that it provides useful insight in agreement with field observations given the scale of the present investigation. We also
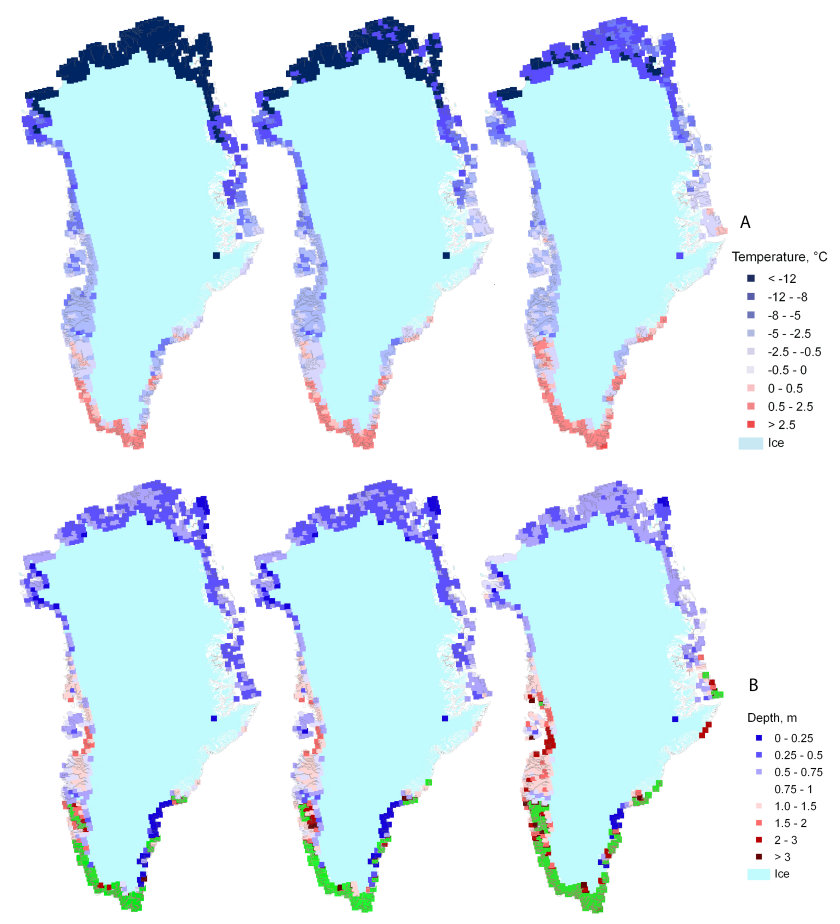

Fig. 5. (A) Annual average ground temperature distribution at $2 \mathrm{~m}$ depth in sediment with organic layer averaged over the periods 1955-1965, 1995-2005, and 2065-2075.(B) Active layer depth distributions for areas with sediments and organic matter averaged over the periods 1955-1965, 1995-2005, and 2065-2075. The green color represents a permafrost free zone.

conclude that potential permafrost degradation is a risk in all of inhabited West Greenland around and north of Nuuk, and the risk should be evaluated for each individual construction project.

\subsection{Model validation and implications on a community scale}

In order to validate the results of our model and classification scheme, we estimated the predicted effects of permafrost degradation at the grid cells representing the two major towns of Sisimiut and Ilulissat. The towns are both located in the discontinuous permafrost region of West Greenland (Christiansen and Humlum, 2000). We compare here the model results with observed data from the two localities.

\subsubsection{Results and implications at Sisimiut}

Sisimiut is situated on the west coast of Greenland at approximately $66.2^{\circ} \mathrm{N}$ and $53.7^{\circ} \mathrm{W}$ (see Fig. 6).

In the 1960s and 1970s, the Geological Survey of Greenland operated a ground temperature measurement station in Sisimiut (Olesen et al., 2003), with temperature sensors down to a depth of $9 \mathrm{~m}$. The availability of this data and a few years of modern data (Christiansen et al., 2010) allow 


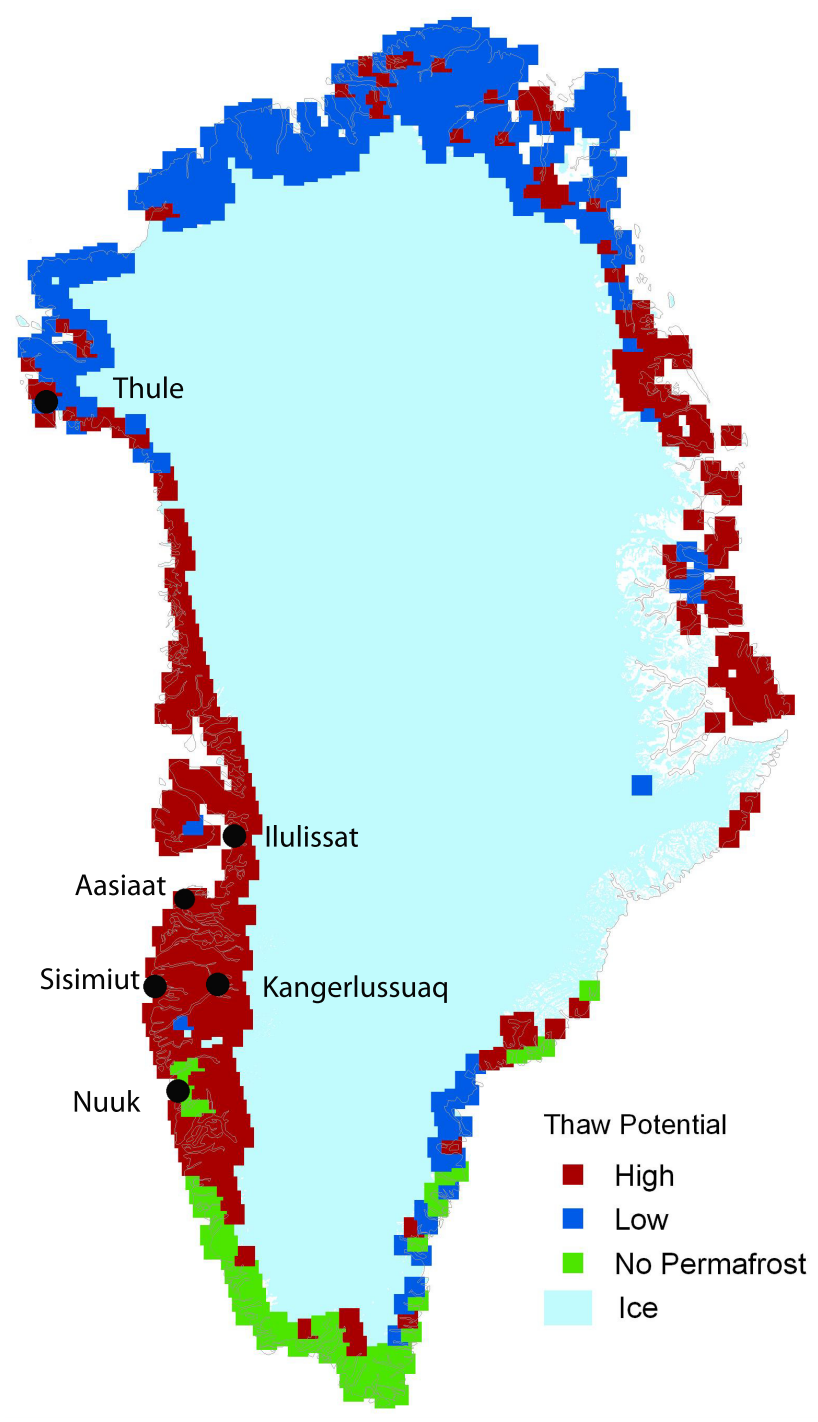

Fig. 6. Permafrost Thaw Potential (PTP) classification for Greenland. High thaw potential coresponds to a PTP value greater than $2.5 \mathrm{~m}$. The potential active layer depth increase was calculated by subtracting current sediment active layer depths (1995-2005) from future bedrock active layer depths (2055-2065).

us to investigate the model performance over more than a decade. Figure 7 shows a plot of the modelled ground temperature data as well as the observed data. The modelling results show average ground temperatures of $-2.55,-3.06$ and $-3.09^{\circ} \mathrm{C}$ for $0.25,1.5$ and $9 \mathrm{~m}$ depths respectively, which is lower than the observed ground temperatures of -0.79 , -0.06 and $-0.01^{\circ} \mathrm{C}$ at the same depths.

With Sisimiut situated in the discontinuous permafrost zone, we have observed ground temperatures to vary widely on a local scale depending on surface conditions, lithology, water content, slope aspect etc. While the location chosen for the ground temperature observations by Olesen in 1967 can be only barely categorized as permafrost (at that time),

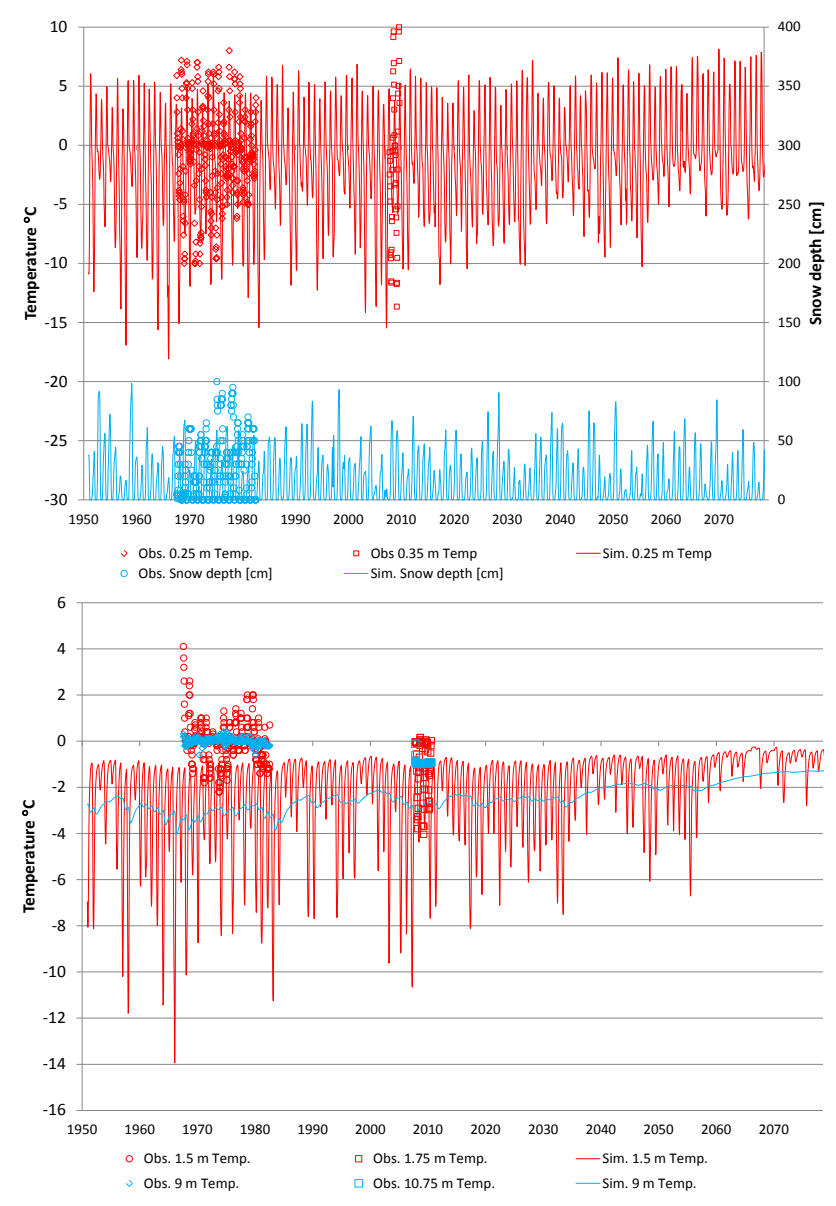

Fig. 7. Observed and simulated snow depth and ground temperature at $0.25 \mathrm{~m} \mathrm{(A)} \mathrm{and} \mathrm{ground} \mathrm{temperatures} \mathrm{at} 1.5 \mathrm{~m}$ and $9 \mathrm{~m} \mathrm{(B)} \mathrm{near}$ the Sisimiut area for the entire simulation period. The older data from Olesen et al. (2003) and the recent data collected as part of the present study are from different locations in Sisimiut.

other locations in town are known to have ice rich permafrost (Ingeman-Nielsen, 2005; Ingeman-Nielsen et al., 2007). Obviously this local scale variation cannot be described using a regional model with a grid size of $25 \mathrm{~km}$. With this in mind, the agreement between observed and modelled ground temperature data seems reasonable with a slight cold bias. The soil at the measurement site of Olesen in Sisimiut is coarser grained and better drained than it is assumed in the model, possibly explaining part of the discrepancy with the model results. Other effects may be related to the discretization of the topographical relief used in the $25 \mathrm{~km} \mathrm{RCM}$, which results in the grid cell being at higher average elevation than the actual field site, causing a colder forcing temperature due to the lapse rate.

As the model forecasts a warming trend in the $9 \mathrm{~m}$ depth ground temperatures over the course of the century, and present modelled permafrost temperatures for the period 2065-2075 is as high as $-1.3^{\circ} \mathrm{C}$, the observed on-going 
permafrost degradation is expected to continue and accelerate in the Sisimiut area.

We have calculated the PTP for the Sisimiut region to be $4.5 \mathrm{~m}$, which classifies as high PTP. Applying the risk assessment flow diagram, all permafrost areas with basin deposits of fine grained marine deposits classify as medium or high risk zones depending on the ice content in the sediments.

\subsubsection{Results and implications at Ilulissat}

Ilulissat is situated in the inner part of the Disko Bay at approximately $69.2^{\circ} \mathrm{N}$ and $51.1^{\circ} \mathrm{W}$ (see Fig. 6). The locality is a well-documented example of saline permafrost (Foged and Bæk-Madsen, 1980; Ingeman-Nielsen et al., 2008). Detailed geotechnical investigations in this area (Foged, 1979) have shown that the fine grained marine deposits are not completely leached. Comparisons of pore water chemistry show that the extent of desalination seems to be related to elevation. Areas at higher elevations show deeper extent of desalination due to longer exposure before permafrost aggradation starts. The lower elevation areas are desalinated only in the upper 3-6 $\mathrm{m}$ with chloride concentrations nearing those of seawater in the deeper parts of the profile towards bedrock.

The ice content of the sediments in the Ilulissat area depends on both salinity and the availability of water at the time of permafrost formation, and spans a wide range from no excess ice to super saturated segments due to the presence of ice lenses (Ingeman-Nielsen et al., 2008).

In addition to the previously described regional model run, we have also modelled a completely unleached saline situation for Ilulissat, using a freezing point depression of $2{ }^{\circ} \mathrm{C}$ for all layers in the model $\left(\mathrm{D}=-2^{\circ} \mathrm{C}\right)$.

Figure 8 illustrates the observed and simulated ground temperature evolution for sedimentary deposits in the Ilulissat area for completely leached as well as saline conditions at the depths of 2.5 and $15 \mathrm{~m}$. The model results show that the presence of residual salinity in the sediment causes a significant attenuation of the amplitudes of the annual temperature oscillations, due to the additional energy consumed/produced during phase changes in the deeper active layer. The results indicate an increase of a little more than $1{ }^{\circ} \mathrm{C}$ in mean annual ground temperature by $2065-2075$ as compared to $1995-$ 2005.

The Geological Survey of Greenland also operated a ground temperature measurement station in Ilulissat (Olesen, 2003 ) in the 1960s and 1970s. The Ilulissat ground temperature station was equipped with temperature sensors down to a depth of $15 \mathrm{~m}$. New data more recently collected from the upper $4 \mathrm{~m}$ of permafrost close to the airport in Ilulissat is also presented. The observed data has been added to the Fig. 8 for comparison.

The simulation results from $2.5 \mathrm{~m}$ depth and unleached conditions fit well with the observed data, although winter temperatures are generally colder in the model prediction.

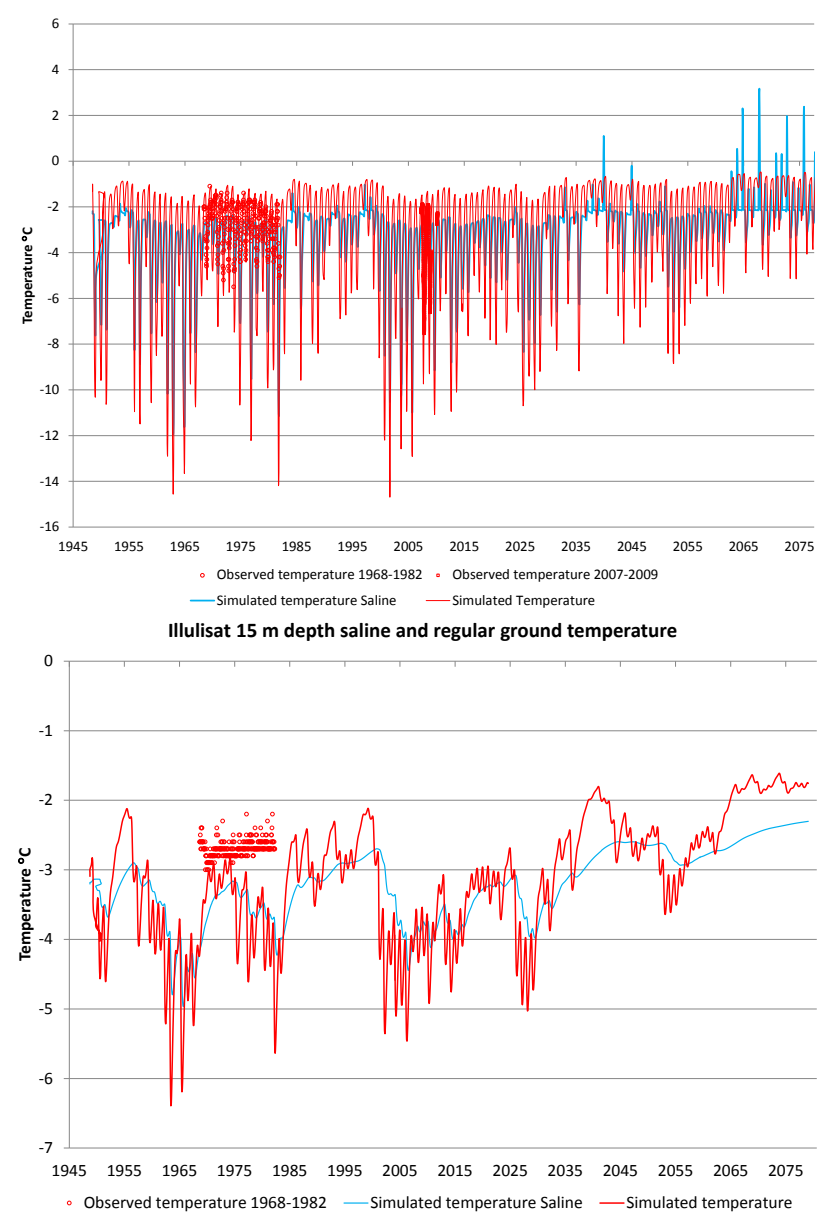

Fig. 8. Temperature time series for an area near Ilulissat for $2.5 \mathrm{~m}$ depth (A) and $15 \mathrm{~m}$ depth (B), comparing saline and regular temperature simulation in a sediment basin. The older data from Olesen (2003) and the recent data collected as part of the present study are from different locations in Ilulissat.

Deeper permafrost temperatures of the Ilulissat simulations have a cold bias compared to observed data (Olesen, 2003). The agreement between observed and modelled ground temperatures is very good, with average temperature differences within $1{ }^{\circ} \mathrm{C}$. This is impressive when keeping in mind that the forcing climatic parameters - in particular the snow depth - was exclusively simulated by the HIRHAM, and thus subject to the challenges previously discussed.

The calculated PTP for the Ilulissat region is $3.7 \mathrm{~m}$ for the completely leached condition and classifies as high PTP. As was the case with the Sisimiut area, application of the risk assessment flow diagram, results in all permafrost areas with basin deposits of fine grained marine deposits classifying as medium or high risk zones depending on the ice content in the sediments. 


\section{Discussion}

We compare ten year averaged ground temperatures in Figs. $4 \mathrm{a}$ and $5 \mathrm{a}$. The data shows a modest amount of change over the simulation period from 1950 to 2075 . Even at higher spatial resolution $(25 \mathrm{~km})$, compared with global circulation models, the HIRHAM regional climate model simulation of air temperatures and snow depth is relatively coarse when comparing it with the heterogeneity of the landscape (Stendel et al., 2008b). The north-south gradient of the climate matches the observed climate reasonably well as provided by (Christiansen and Humlum, 2000). Improvement in resolution is needed to simulate the smaller scale dynamics from the coast inland, considering the numerous fjords along the coast. Temperatures in the northern part of Greenland seem to be most affected by warming. The active layer thickness is sensitive to the warming trend.

One of the drawbacks of present state-of-the-art regional scale permafrost models is their lack of ability to handle segregated ice in the sediments. The model applied here can handle high volumetric water contents, but as the model is not coupled to a groundwater flow and drainage model, such high water contents would be static in location and thus cause unrealistic distribution of water in the active layer upon permafrost thaw. The model has therefore been implemented using water contents on the order of natural porosity of the sediments, causing probably an underestimation of ice content in the upper part of the permafrost for some locations in a particular area of a simulation domain, in other areas ice content may be overestimated within the same domain.

Warming in the Sisimiut and Ilulissat region causes the active layer thickness to increase. For sediment areas in Sisimiut, which can be expected to gain importance for new development of infrastructure, the model predicts active layer deepening from approximately $1 \mathrm{~m}$ under present-day conditions to $2 \mathrm{~m}$ in 2065-2075, assuming constant ice content with depth and resulting from our selection of soil parameters slightly deeper depths for the region around Ilulissat. The large amount of ground ice observed in these sediments could result in large soil surface settlement. The PTP shows a high risk for both Sisimiut and Ilulissat regions with potential increase in active layer of 3.5 and 2.7 respectively.

The risk of permafrost degradation for engineering structures is strictly related to the presence of sediment around the community of interest. The current conditions in sediments around larger communities like Sisimiut and Ilulissat would not support construction of larger buildings using traditional foundations. The permafrost soil temperatures are near the thawing point in Sisimiut as well as Ilulissat, when taking into account the freezing point depression caused by pore water salinity. As indicated by the PTP the additional stress of climate warming and soil surface disturbance makes the situation more unsuitable.
Due to its present resolution $(25 \mathrm{~km})$, the applied PTP approach does not resolve local scale variations in topographical and other site specific conditions, and thus can technically not be used as an accurate prediction for individual projects without additional input from local parameters. However, as demonstrated with the towns of Ilulissat and Sisimiut, the modelled PTP places these areas in high PTP zones with a considerable margin, and we therefore find it reasonable to use the PTP classification as an estimate, when site specific thermal models are lacking. With the inclusion of local information on geological conditions and ice contents - and of course local thermal conditions when possible - the PTP could be very useful for site specific permafrost analysis to determine the particular permafrost degradation risk for that site. This site specific permafrost degradation risk designation will assist with design and expense evaluation due to mediation techniques against aversive effects of construction on permafrost.

\section{Conclusions}

In this proof-of-concept study, we have presented a modelling system consisting of the RCM HIRHAM4 with boundary conditions provided by a GCM. The output is used to drive the GIPL 2.1 spatially distributed permafrost model. The modelled ground temperatures are used as input to a risk zone assessment, thereby linking climate and permafrost science to engineering decisions in one complete workflow.

\subsection{Modelling results}

Permafrost temperatures were simulated for Greenland and it was found that most areas are warming as the climate warms over the period from 1950 to 2075. Permafrost temperatures in the northern portion of the country are strongly affected by warming winter temperatures whereas the temperatures in the south are buffered by melting ground ice and deepening of the active layer. The active layer thickness is increasing with time for bedrock and sedimentary substrates indicating degrading permafrost.

We quantified the risk of permafrost degradation using a quantity which we call the Permafrost Thaw Potential (PTP). Most of the terrestrial regions in Greenland south of $76^{\circ} \mathrm{N}$ are classified as high PTP in accordance with our observations in Greenlandic towns. This calls for careful risk evaluations in the design phase of construction projects. We hope practitioners may find our risk evaluation methodology useful for such purposes.

Future very high resolution simulations of permafrost for individual engineering applications will also require very high resolution data acquisition and more sophisticated physical relations for snow, surface energy balance and hydrological parameters. 


\subsection{Geotechnical recommendations}

Infrastructure and buildings that are currently not resting on bedrock will become exposed to uneven settling of sediments and potential degradation. We expect construction and maintenance costs of buildings and infrastructure in Greenland to increase dramatically if current practices are not adapted to the warming conditions. We have suggested a simple risk assessment methodology developed specifically for Greenlandic conditions that could help local municipal governments, civil engineers and contractors to assess the local risk of permafrost degradation, and help in determining the proper site investigation strategies and foundation practices for individual construction projects.

The Sisimiut and Ilulissat areas are both in risk of severe permafrost degradation due to the presence of permafrost with temperatures close to the freezing point of the ground materials. For the town of Ilulissat in particular, the combination of saline permafrost with a high ice content and a high Permafrost Thaw Potential results in a high risk scenario where construction on fine-grained sedimentary deposits with permafrost should be avoided whenever possible, either by excavation of the sediments or by construction of point bearing piles extended to bedrock surface.

Acknowledgements. Funding for this project was provided by the National Science Foundation under grant no: ARC-0612533. We would also like to thank our collaborators from ASIAQ, the DMI and DTU, as well as ARSC for computational support.

Edited by: R. Rigon

\section{References}

ACIA: Impacts of a Warming Arctic, Arctic Climate Impact Assessment (Highlights), Cambridge University Press, Cambridge, 110 pp., 2004.

Anisimov, O. A. and Nelson, F. E.: Permafrost zonation and climate change in the northern hemisphere: results from transient general circulation models, Climatic Change, 35, 241-258, doi:10.1023/a:1005315409698, 1997.

Anisimov, O. A., Shiklomanov, N. I., and Nelson, F. E.: Variability of seasonal thaw depth in permafrost regions: a stochastic modeling approach, Ecol. Model., 153, 217-227, 2002.

Bennike, O. and Björck, S.: Chronology of the last recession of the Greenland Ice Sheet, J. Quaternary Sci., 17, 211-219, 2002.

Birkholm, J., Brandt, I., and Foged, N.: Deterioration of Permafrost in Thule - Implication for Road Construction in Greenland, International Conference, Arctic Roads, Operating, maintaining and building roads in a climatically challenging environment, Sisimiut, 1, 70-78, 2007.

Christensen, J. H. and Kuhry, P.: High resolution regional climate model validation and permafrost simulation for the EastEuropean Russian Arctic., J. Geophys. Res., 105, 29647-29658, 2000.
Christensen, J. H., Christensen, O. B., Lopez, P., Van Meijgaard, E., and Botzet, M.: The HIRHAM4 Regional Atmospheric Climate Model, Scientific Report DMI, Danish Meteorological Institute, 51 pp., 1996.

Christiansen, H. H. and Humlum, O.: Permafrost, Topografisk Atlas Grønland, edited by: Jakobsen, B. H., Böcher, J., Nielsen, N., Guttesen, R., Humlum, O., and Jensen, E., C. A. Reitzets Forlag, Copenhagen, 32-35, 2000.

Christiansen, H. H., Etzelmuller, B., Isaksen, K., Juliussen, H., Farbrot, H., Humlum, O., Johansson, M., Ingeman-Nielsen, T., Kristensen, L., Hjort, J., Holmlund, P., Sannel, B., Sigsgaard, C. J., Foged, N. N., Bilkra, L., and Pernosky, M. R.: The Thermal State of Permafrost in the Nordic Area during the International Polar Year 2007-2009, Permafrost Periglac., 21, 156-181, 2010.

Daanen, R. P., Romanovsky, V. E., Walker, D. A., and LaDouceur, M.: High Resolution, Surface and Subsurface, Survey of a Nonsorted Circle System, Ninth Internatonal Confererence on Permafrost, 1, 321-326, 2008.

Dethloff, K., Schwager, M., Christensen, J. H., Kiilsholm, S., Rinke, A., Dorn, W., Jung-Rothenhäusler, F., Fischer, H., Kipfstuhl, S., and Miller, H.: Recent Greenland accumulation estimated from regional climate model simulations and ice core analysis, J. Climate, 15, 2821-2832, 2002.

Foged, N.: Engineering Geological Investigations of Quaternary Marine Clay Deposits on West Greenland, Ph.D., The Institute for Applied Geology, Technical University of Denmark, Copenhagen, 1979 (in Danish).

Foged, N. and Bæk-Madsen, C.: Jakobshavn Airport thermal stability in marine deposits. Second International Symposium on Ground Freezing, Second International Symposium on Ground Freezing, Trondheim, 1980.

Food and Agriculture Organization of the United Nations, F.: Soil map of the world, volumes I-X, Paris, 1978.

Goodrich, L. E.: The influence of snow cover on the ground thermal regime, Can. Geotech. J., 19, 421-432, 1982.

Ingeman-Nielsen, T.: Geophysical Techniques Applied to Permafrost Investigations in Greenland, Ph.D., BYGDTU R-123, Technical University of Denmark, Copenhagen, 177 pp., 2005.

Ingeman-Nielsen, T., Clausen, H., and Foged, N.: Engineering Geological and Geophysical Investigations for Road Construction in the Municipality of Sisimiut, West Greenland, Proceedings from the International Conference, Arctic Roads, Operating, maintaining and building roads in a climatically challenging environment, 1, 53-61, 2007.

Ingeman-Nielsen, T., Foged, N., Butzbach, R., and Jorgensen, A. S.: Geophysical Investigations of Saline Permafrost at Ilulissat, Greenland, Proceedings of the Ninth International Conference on Permafrost, 1, 773-778, 2008.

IPCC: IPCC Summary for Policy Makers: Climate Change 2001: The Scientific Basis. Contribution of Working Group I to the Third Assessment Report of the Intergovernment Pannel on Climate Change, edited by: Houghton, J. T., Ding, Y., Griggs, D. J., Noguer, M., van de Linden, P. J., Dai, X., Mashell, K., and Johnson, C. A., Cambridge University Press, Cambrige, 1, 1-20, 2001.

IPCC: Climate Change 2007: Synthesis Report. Contribution of Working Groups I, II and III to the Fourth Assessment Report of the Intergovernmental Panel on Climate Change, edited by: Pachauri, R. K. and Reisinger, A., Geneva, Switserland, 1, 
104 pp., 2007.

Jungclaus, J. H., Keenlyside, N., Botzet, M., Haak, H., Luo, J.J., Latif, M., Marotzke, J., Mikolajewicz, U., and Roeckner, E.: Ocean circulation and tropical variability in the coupled model ECHAM5/MPI -OM., J. Climate 19, 3952-3972, 2006.

Lawrence, D. M. and Slater, A. G.: The contribution of snow condition trends to future ground climate, Clim. Dynam., 34, 969-981, doi:10.1007/s00382-009-0537-4, 2008.

Lovell, C.: Temperature effects on phase composition and strength of partially frozen soil Highway, Res. Board Bull., 168, 74-95, 1957.

Lucas-Picher, P.: Very high-resolution regional climate modeling over Greenland with HIRHAM5, in preparation, 2011.

Marchenko, S. S., Romanovsky, V. E., and Tipenko, G. S.: Numerical Modeling of Spatial Permafrost Dynamics in Alaska, in Proceedings of the Ninth International Conference on Permafrost, June 29-July 3, Fairbanks, Alaska, 2, 1125-1130, 2008.

Marsland, S. J., Haak, H., Jungclaus, J. H., Latif, M. and Röske, R.: The Max-Planck-Institute global ocean/sea ice model with orthogonal curvilinear coordinates. Ocean Modelling 5, 91-127, 2003.

May, W.: Climatic changes associated with a global $" 2^{\circ} \mathrm{C}$ stabilization" scenario simulated by the ECHAM5/MPI-OM coupled climate model, Clim. Dynam., 31, 283-313, 2008.

Nakićenović, N., Alcamo, J., Davis, G., de Vries, B., Fenhann, J., Gaffin, S., Gregory, K., Grübler, A., Jung, T. Y., Kram, T., La Rovere, E. L., Michaelis, L., Mori, S., Morita, T., Pepper, W., Pitcher, H., Price, L., Riahi, K., Roehrl, A., Rogner, H.-H., Sankovski, A., Schlesinger, M., Shukla, P., Smith, S., Swart, R., van Rooijen, S., Victor, N., and Dadi, Z.: IPCC Special Report on Emissions Scenarios., Cambridge, United Kingdom and New York, NY, USA., 599, 2000.

Nelson, F. E. and Outcalt, S.: A computational method for prediction and regionalisation of permafrost, Arctic Alpine Res, 19, 279-288, 1987.

Nelson, F. E., Anisimov, O. A., and Shiklomanov, N. I.: Subsidence risk from thawing permafrost, Nature, 410, 889-890, 2001.

Nicolsky, D. J., Romanovsky, V. E., Alexeev, V. A., and Lawrence, D. M.: Improved modeling of permafrost dynamics in a GCM land-surface scheme, Geophys. Res. Lett., 34, L08501, doi:0.1029/2007g1029525, 2007.

Nicolsky, D. J., Romanovsky, V. E., and Panteleev, G. G.: Estimation of soil thermal properties using in-situ temperature measurements in the active layer and permafrost, Cold Reg. Sci. Technol., $55,120-129,2009$.

Olesen, O. B.: Shallow Borehole Temperatures, Ilulissat, Greenland, Greenlandic Geological Survey (GEUS), Distributed by National Snow and Ice Data Center/World Data Center for Glaciology, 2003.

Olesen, O. B., Foged, N., van Tatenhove, F. G. M., and Christiansen, H. H.: Active-Layer and Permafrost Temperatures, Sisimiut (Holsteinsborg), Greenland, Greenlandic Geological Survey, GEUS, Distributed by National Snow and Ice Data Center/World Data Center for Glaciology digital media, 2003.

Rasch, M.: Holocene Relative Sea Level Changes in Disko Bugt, West Greenland, J. Coast. Res., 16, 306-315, 2000.

Rinke, A., Dethloff, K., Cassano, J., Christensen, J. H., Curry, J. A., Du, P., Girard, E., Haugen, J. E., Jacob, D., Jones, C. J., Køltzow, M., Laprise, R., Lynch, A. H., Pfeifer, S., Serreze, M. C., Shaw,
M. J., Tjernström, M., Wyser, K., and Zagar, M.: Evaluation of an Ensemble of Arctic Regional Climate Models: Spatiotemporal fields during the SHEBA year, Clim. Dyn., 26, 459-472, http://dx.doi.org/10.1007/s00382-005-0095-3, 2006.

Riseborough, D. W., Shiklomanov, N., Etzelmüller, B., Gruber, S., and Marchenko, S.: Recent advances in permafrost modelling, Permafrost Periglac., 19, 137-156, 2008.

Roberts, D. H., Long, A. J., Schnabel, C., Davies, B. J., $\mathrm{Xu}$, S., Simpson, M. J. R., and Huybrechts, P.: Ice sheet extent and early deglacial history of the southwestern sector of the Greenland Ice Sheet., Quaternary Sci. Rev., doi:10.1016/j.quascirev.2009.07.002, 2009.

Roeckner, E., Brokopf, R., Esch, M., Giorgetta, M., Hagemann, S., Kornblueh, L., Manzini, E., Schlese, U., and Schulzweida, U.: Sensitivity of simulated climate to horizontal and vertical resolution in the ECHAM5 atmosphere model, J. Climate, 19, 3771-3791, 2006.

Romanovsky, V. E. and Osterkamp, T. E.: Interannual variations of the thermal regime of the active layer and near-surface permafrost in northern Alaska, Permafrost Periglac., 6, 313-335, 1995.

Romanovsky, V. E., Burgess, M., Smith, S., Yoshikawa, K., and Brown, J.: Permafrost temperature records: indicators of climate change, EOS, AGU Transactions, 83, 589-594, 2002.

Romanovsky, V. E., Smith, S. L., and Christiansen, H. H.: Permafrost Thermal State in the Polar Northern Hemisphere during the International Polar Year 2007-2009: a Synthesis, Permafrost Periglac., 21, 106-116, doi:10.1002/Ppp.689, 2010.

Sazonova, T. and Romanovsky, V. E.: A model for regional scale estimation of temporal and spatial variability of active layer thickness and mean annual ground temperatures, Permafrost Periglac., 14, 125-139, 2003.

Sergeev, D. O., Tipenko, G. S., and Romanovsky, V. E.: Mountain permafrost thickness evolution under influence of long-term climate fluctuations (results of numerical simulations), 8th International Conference on Permafrost, Zurich, 1017-1021, 2003.

Stendel, M. and Christensen, J. H.: Impact of global warming on permafrost conditions in a coupled GCM, Geophys. Res. Lett., 29, 1632, 4 pp., doi:10.1029/2001GL014345, 2002.

Stendel, M., Romanovsky, V. E., Christensen, J. H., and Sazonova, T.: Using dynamical downscaling to close the gap between global change scenarios and local permafrost dynamics, Global Planet. Change, 56, 203-214, 2007.

Stendel, M., Christensen, J., and Petersen, D.: Arctic Climate and Climate Change with a Focus on Greenland, in: High-Arctic Ecosystem Dynamics in a Changing Climate - Ten Years of Monitoring and Research at Zackenberg Research Station, Northeast Greenland, edited by: Meltofte, H. et al., Advances in Ecological Research, 40, 13-43, doi:10.1016/S0065-2504(07)00002-5, 2008a.

Stendel, M., Christensen, J. H., Adalgeirsdottir, G., Daanen, R. P., Marchenko, S. S., and Romanovksy, V. E.: The fate of Greenland's permafrost; results from high-resolution transient climate simulations, Ninth International Conference on Permafrost, Fairbanks, 1705-1709, 2008b.

Tipenko, G. S.: Simulation of Soil Freezing and Thawing: Direct and Inverse Problems, EOS Trans. Fall meeting, AGU, San Fransisco, F551, 2001. 
Walsh, J. E., Chapman, W. L., Romanovksy, V. E., Christensen, J. H., and Stendel, M.: Global climate model performance over Alaska and Greenland, J. Climate, 21, 6156-6174, doi:10.1175/2008JCLI2163.1, 2008.

Weidick, A.: Glaciation and the Quaternary of Greenland, Geology of Greenland, edited by: Escher, A. and Watt, W. S., Copenhagen: Geological Survey of Greenland, 1976.
Yoshikawa, K. and Hinzman, L. D.: Shrinking thermokarst ponds and groundwater dynamics in discontinuous permafrost near Council, Alaska, Permafrost Periglac., 14, 151-160, doi:10.1002/ppp.451, 2003.

Zhang, T. J.: Influence of the seasonal snow cover on the ground thermal regime: an overview, Rev. Geophys., 43, RG4002, doi:10.1029/2004RG000157, 2005. 